\title{
SOUTH ASIAN HEROES
}

\section{CELEBRATING SOUTH ASIAN HERITAGE - AUG 2020}

The United Kingdom National Health Service (NHS) staff and students have been working tirelessly throughout the pandemic in a multitude of ways, including caring for patients, volunteering their time or being involved in research and education. People of Asian origin make up $29.7 \%$ of the NHS medical workforce1. In recognition of South Asian Heritage Month, we asked our readers to nominate health care workers of South Asian origin who have demonstrated their tenacity, innovation and excellence in recent months.

\section{NHS HERO: SONALI DUTTA-KNIGHT}

Ninety five percent of the NHS doctors who died from Coronavirus were from Black and Minority Ethnic (BAME) groups. From March, this concerned me. I was just a normal jobbing General Practitioner, wife, mother... would anyone listen? I started discussions through social media. I researched and published articles (notably British Medical Journal Leader). I created the group 'Healthcare Professionals Against Racism' which has over 1000 members. I was invited to advise a group of Members of Parliament in an all-party conference to discuss strategies to protect BAME NHS staff. I'm even now running for the Royal College of General Practitioners Council primarily because I want to raise the voices of all doctors of colour.

\section{NHS HERO: SARISHKA SINGH}

The COVID-19 pandemic washed over our medium sized District General Hospital like a tidal wave, filling staff with fear and then

\author{
Curated by Triya Chakravorty \\ University of Oxford, UK
}

triya.chakravorty@queens.ox.ac.uk

DOI: $10.38192 / 13.3 .20$

\begin{tabular}{l} 
Article Information \\
\hline Submitted 31.08 .2020 \\
Published 01.09.2020 \\
Creative Commons Licence v4.0 CC-BY-ND-4.0
\end{tabular}

receded, leaving us battling exhaustion and depression. As a Foundation Year 1, I did not expect my year to be uprooted like it was. I witnessed my environment suddenly changing and the bustling ward that I had known morphed into a unrecognisable area of sick and dying COVID patients. The months that followed were hellish, but still we rallied against the seemingly never-ending tide of admissions with energy and vigour despite staff shortages, succumbing to the virus ourselves and physical and mental exhaustion.

\section{NHS HERO: VEENA NAIK}

I would like to nominate my friend and ex colleague Veena Naik who is a Consultant Anaesthetist at James Paget University Hospital NHS Foundation Trust, Great Yarmouth. Her husband, after undergoing a kidney transplant has recently had to go back to dialysis due to rejection and go back on the transplant waiting list. During the pandemic she had to stay away from him to be able to work for NHS as he would have been at risk. Nominated by Nilanjana Singh. 


\section{NHS HERO: MUKESH CHUGH}

This picture was taken after 18 hours of dealing with Covid-19 patients on one of the most exhausting nights of my career. Prostration was not due to the number of hours or number of patients; but was due to donning and doffing, getting dehydrated while breathing through the mask and fear of unknown.

\section{NHS HERO: ANITA GHEI}

Due to medical risk assessments, my clinical role as a dentist was impacted. Consequently, I was enrolled into restorative and oral surgery telephone triaging. This service provides 'Advice, Analgesia and Antibiotics', ensuring patients meeting the urgent criteria are seen. Triaging allows adaption and development of communication skills in order to assess, differentially diagnose and manage dental problems without seeing the patient. This role has included many challenges: language barriers, decisions associated with shielded patients and restricted services of local anaesthetic clinics only. However, this experience has highlighted the importance of oral health and the need for dental service provision.

\section{NHS HERO: AIYAPPA BIDDANDA}

The initial two weeks when Italy went into lockdown the hospital and government were very laid back. This led to the hospitals having no clear plan of action and the initial spread of disease. I was distraught, feeling scared and angry as a night medical registrar where I had to make quick decisions. The lockdown was not as hectic as I expected it to be, but I had to manage staff fears/ safety on my ward with only surgical masks and plastic aprons which left me feeling the same anger towards the hospital management and lack of clear leadership.

\section{REFERENCE}

1 NHS workforce - Ethnicity Facts and Figures, <https://www.ethnicity-factsfigures.service.gov.uk/workforce-andbusiness/workforce-diversity/nhsworkforce/latest\#by-ethnicity> (2020). 